\title{
Peter Sloterdijk's Technopolitics. How Technology Redesigns the Environment and the Polis
}

\author{
Cecilia Della Torre \\ (Università Cattolica del Sacro Cuore di Milano; cecilia.dellatorre@unicatt.it) \\ ORCID: 0000-0001-9497-2270
}

\begin{abstract}
This paper will analyse the role played by technology in Peter Sloterdijk's theory, where he seeks to redefine and reconstruct ethics, society and democracy. Indeed, the philosopher's project is to build a new kind of society, which risks being antidemocratic and elitist: technopolitics. This lemma refers to Sloterdijk's reconfiguration of the social structure through the elimination of the human rights paradigm in a technological and anti-egalitarian manner. In order to do this, Sloterdijk redesigns the environment as a dangerous place whose rules cannot be followed, and which must be reshaped through technology. Hence, the philosopher reduces ethics to technology, and reinterprets society on the basis of new techno-ethical premises which support a hierarchical and selective new polis.
\end{abstract}

Keywords: Sloterdijk; environment; technopolitics; human zoo; democracy; relationship.

\section{Introduction}

By 'technopolitics', the author of this paper refers to Sloterdijk's philosophical project to redesign a polis around a redefinition of the meaning and the importance of technology1. The aim of this paper is to describe and critically analyse how this new social structure has its foundations in a redefinition of the environment as an evil place - rather than a neutral one, which mankind must redesign via technology. The environment is considered as a danger that human beings need to fight against in order to remodel nature and establish a new kind of artificial one. Referring to the metaphor of the biblical Ark, as we will see later on, Sloterdijk shows how nature represents the universal flood, the wet evil, against which the Ark - a technological tool - saves mankind as well all the other species. Therefore, there is no space left for a rehabilitation of the natural dimension: 'man's right to inhabit the original date of what is natural is lost for all time and must be placed on a good new, formal footing'2 (Sloterdijk 2014, 241). Humans need to design

1 Article proofread by Stephen Dersley (ORCID:0000-0002-6765-8590)

2 All quotes from this book are translated by the author. 
a new environment in which they can survive safely, and the only way to do so is via technology.

Now, this new understanding of the concept of nature leads to the formulation of an antidemocratic and discriminatory polis, based on the distinction between selectors and selected. While the formers are elevated and saved by technology, the latter are expelled because of technology. This new social structure coincides with a techno-polis.

Therefore, this paper seeks to analyse and evaluate Sloterdijk's theoretical proposal and ultimately assess whether his philosophical speculation is coherent and based on solid assumptions, or not. The crucial role Sloterdijk assigns to technology will be the fil rouge through which the author will be following the various twists and changes the philosopher makes to his approach in order to try to ensure his speculation remains integral. The final aim is to show how Sloterdijk's theorization presents too many ambiguities which ultimately lead to the collapse of his entire project.

\section{Technology as a Denial of the Environment}

In his work, Sloterdijk uses technology to refer to a safe haven, as opposed to a natural and evil environment that has to be modified and redefined by humans. Indeed, Sloterdijk refuses the idea of nature as the protective good mother of every human being. According to him, human beings can no longer find safety and protection in nature, but rather they do so in their own actions and the related by-products. Therefore, technology appears to be the key to human salvation against this dangerous environment. In order to explain what this new understanding of technology truly implies, Sloterdijk refers to the image of the Ark. The Ark is presented as „a mechanical uterus in which life is possible and is developed as opposed to a non-maternal environment (...) indeed, after the universal flood, nature can no longer claim unreservedly to be an entirely good mother". Sloterdijk uses this reference to the biblical event in order to underline how nature can no longer be considered a protection for humans: „mankind will in future be condemned to provide for itself with the help of God. This marks the beginning of history as a technological era; the true human era must be calculated not from creation, but rather 'from the receding of the waters'” (Sloterdijk 2014, 239-40).

The philosopher uses the Ark because he believes it represents a revolutionary symbol which establishes a new starting point in human history. The Ark refers to an internal, artificial and closed world: the only possible environment for humans. It is defined as „the autonomous, absolute house, free from contexts, without neighbours; it embodies in an exemplary way the denial of the environment through an artificial structure". This is the first and primary realization of the autogenous container, a completely new project: „the idea of a group's self-protection and self-circumvention (Selbstumgebung) against an external world that has become impossible" (Sloterdijk 2014, 237).

Now, it is clear how Sloterdijk wants to overturn the role once played by nature 
with technology in order to redefine it as the fundamental point of reference for humans. Hence, he uses the Ark to underline how humans, thanks to technology, are able to survive and to adapt to their surrounding environment; he therefore fully substitutes nature with technology.

Notwithstanding, this overturning is not without consequences: indeed, „in every fantasy of the Ark, the selection of the few is affirmed as a sacred necessity; many are invited, but few get on board".

This is a necessary selection between those who succeed and those who do not: Sloterdijk theorizes a theology of survival, a theology of selection, to justify his elitist project at a higher level: „For those who have the moral and logical necessity to imagine ways of salvation in a universalistic way, a hard to bear restriction appears here" (Sloterdijk 2014, 246-47).

In his misunderstanding of the biblical passage, he uses this episode of the Ark to show how only the best can save themselves, thanks to technology and God's blessing even though it seems that there is no more need for God himself.

Now, using the Ark as a way to introduce technology as the new paradigm of society, Sloterdijk postulates a new environment justified by the fact that the previous paradigm, nature, is no longer a possibility for human beings. According to these premises, universalism is no longer a value, since humans have to defend themselves from an evil nature and thus need to build barriers for protection. The Ark, indeed, represents the first barrier and, because of its own specific nature, it needs to be elitist.

Taking these considerations as a starting point, it is important to note, from a philosophical perspective, the connection created by Sloterdijk in order to support his antidemocratic project, i.e., the techno-polis. Indeed, the assumption of an original dangerous environment for human beings, linked to the idea that technology has to re-create the world in order to make it safe, unavoidably presents the premises for a society based on discrimination. Indeed, as the imagine of the Ark shows, this idea of technology as the only way to salvation designs a technologically advanced polis that is anti-egalitarian and totally indifferent to human rights. Now, the crux of the matter is in this specific approach taken by Sloterdijk: his anti-egalitarian position - often ascribed to him because of his project to eliminate the fatalism of birth, i.e., the control of the natural human origin via genetic manipulation - actually derives from this controversial and problematic interpretation of the environment.

Within this framework, in his Sphere trilogy (Sloterdijk 2011, 2014, 2016) ${ }^{3}$

3 The notion of the sphere is a key pillar of Peter Sloterdijk's theorization: he believes beingin-the-sphere is the constitutive condition of being human. In fact, contrary to Heidegger, who based his theory on time, Sloterdijk focuses his analysis on space, considering space as the real openness from which human beings emerged. The concept of the sphere refers to an original shared and closed spatiality where men live as humans and which constitutes the only way for human existence. The sphere refers to an intermediate condition, between the external unknown and dangerous environment and the internal environment, which is closed, safe and protected. This is the human world, where human beings grow and evolve. Using the sphere as his main reference, the author believes he is placing the human being in a strategic condition, because he 
Sloterdijk defines the history of the world as a uterotechnics, i.e., the history of the attempts to remodel society by recreating the natural uterine condition on social and external grounds. Society, now conceivable as the opposite of nature, is the new artificial environment, the uterotechnics, which saves humans. As the womb protects the child during intrauterine life, society - the Ark - can protect individuals once they come to the world and begin living outside their first container. This is the reason why Sloterdijk refers to the evocative image of the womb, translating it into the technological world with the concept of the Ark, intended as a mechanical uterus, which brings salvation from the wet evil, the environment as such.

Once Sloterdijk has technologically reconfigured the classical conflict between nature and culture, he can use these theoretical premises to state the primacy of technology. This is a crucial passage for the realization of his final project, technopolitics. Indeed, the establishment of a technopolitical system needs to go through this understanding of the environment as a dangerous place whose rules cannot be followed, but which rather must be remodelled and reconfigured. Therefore, Sloterdijk needs to postulate the primacy of technology as the first and most important value. In order to do so, he overturns the relationship between ethics and technology, making technology the new ethical point of reference. This way he can exclusively argue that everything which can be done has to be done, in order to establish a new kind of pyramidal society which is technologically oriented. Technology becomes, in Sloterdijk's theoretical approach, the key to solving all the issues he has highlighted so far.

In order to explain how technology is the destination point of his line of thought, Sloterdijk elaborates „a virtual incubator of zoopolitical protection at the hands of the very State" (Tillería Aqueveque 2020 75), where protection and care for human beings become the formula to indicate control and selection.

Indeed, if Sloterdijk's technological conception of society derives from his understanding of the environment as a dangerous place, it is crucial to deepen its redefinition and realization, on a social level, as a human park.

\section{The Power to Select and Control the Human Zoo}

Sloterdijk affirms the importance of human domestication and human breeding as a way of contributing to the well-being and the enhancement of society. With this idea as a starting point, the philosopher's project becomes explicit: he establishes the terms and grounds on which individuals can be part of society. Once again, Sloterdijk adopts a

is guaranteeing them the necessary protection to evolve and survive by acting on the external environment not subject to its interferences. Sloterdijk uses this concept to reread the whole history of humanity through the category of the sphere. Indeed, he theorizes the existence of microspheres as well as macrospheres, until finally elaborating the notion of 'foams' to indicate the disintegration of the sphere itself. For further information on the development of the sphere, please refer to the Sphere trilogy. For the first Italian monograph on Sloterdijk and his spherology, please refer to Lucci (2011). 
clear elitist perspective, and therefore does not support a democratic vision of society, nor a human rights logic - „Sloterdijk neither is nor wants to be a theorist of equality” (Couture 2016 2). He believes human beings have to earn their place in society and that not everyone can participate in it or occupy positions of power.

Hence Sloterdijk speaks about human breeding and domestication as the first steps towards the creation of a human zoo, i.e., the establishment of a society, that new artificial environment where human beings are controlled and selected in order to establish an enhanced society. Furthermore, he believes the best way to select them is through anthropotechnics. In this context, he analyses two types of anthropotechnics, i.e., the use of technological criteria for deciding on one's inclusion or exclusion in society: a primary type which includes education, taming, disciplining and formation, and a secondary type which consists of specific "direct interventions into the genetic 'text' of individuals" (Sloterdijk 2017a, 127). Indeed, in this secondary type, the redefinition of the environment becomes the justification for redesigning the same genetic constitution of human beings, coinciding with it. For the purposes of this paper, the author will primarily take into consideration the second type of anthropotechnics. In his very famous essay Rules for the Human Park (Sloterdijk 2017b), which caused the Sloterdijk affair ${ }^{4}$, the philosopher criticises the first type of anthropotechnics, which he identifies with humanism: he believes it is a way to control and tame human beings through education and cultural selection ${ }^{5}$.

Sloterdijk is not interested in demolishing the idea of breeding humans - quite the

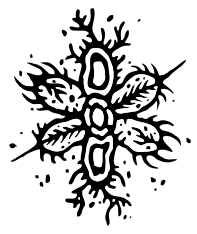
opposite - but he criticises the humane way of doing so. Indeed, he believes "humans voluntarily and deliberately put themselves in 'theme parks', 'human zoos"' because if "being-in-the-world means making worlds", as Eduardo Mendieta explains, "hominization (...) is also a history of the world we have made to cultivate, to breed, to domesticate, to preserve ourselves" (Mendieta 2012, 72).

4 The Sloterdijk affair refers to a very intense debate that took place between Habermas and Sloterdijk after Sloterdijk gave a talk at Castle Elmau in 1999, where he presented his "Rules for the Human Zoo". In this talk he linked his interpretation of humanism to a return to eugenics, in the form of biotechnology; his provocative and very ambiguous arguments paved the way for a variety of interpretations, and Sloterdijk was accused of being a Nazi sympathizer. The scandal was reported on by German newspapers "Die Zeit" and "Der Spiegel", by Thomas Assheuer and Reinhard Mohr, who accused Sloterdijk of proposing a genetic revision of humanity through selection and breeding and of advocating again via prenatal selection the eugenic Nazi ideal, respectively. The author defended himself accusing - besides Assheuer - Habermas, as he was the hidden instigator, claiming that the one who presented himself as the philosopher of the other's inclusion, did not give the chance to have a proper discussion on the topic. This opened a very harsh dispute between the two philosophers that ended with a demonstration of Habermas' guilt and the declaration of the death of critical theory. To see an in-depth analysis of the dispute, please refers to Couture (2016, 74-84). For an Italian reference on the topic, please refer to Calligaris (2011).

5 According to Sloterdijk's interpretation, since humanism has failed its project to present itself as 'a school of human formation' (Sloterdijk 2017b, 204), it is necessary to rethink a way to domesticate humans and subsequently to implement this approach and rebuild society on this new perspective. The philosopher's intent is to show how humanism was also a form of control, albeit a covert one; following and embracing Nietzsche's speculations, Sloterdijk highlights how humanist education hid a form of coercion and a project to tame humanity, maintaining its monopoly through education. 
Just as humanism had established a hierarchy among people based on their active or passive role in the breeding dynamics, controlled by an élite who decided the criteria of selection and exclusion, Sloterdijk aims to create a distinction between humans. More specifically, he seeks to differentiate between smaller human beings who have been bred as domestic animals, and superhumans, who control others through "an artful linking of ethics and genetics" (Sloterdijk 2017b, 208). As Jean-Pierre Couture outlines, "Sloterdijk adopts Nietzsche's perspective by opposing the horizontal trends of democratic equality to the vertical trends of heroic surpassing"(Couture 2016, 37). In fact, Sloterdijk's elitist perspective contemplates genetic selection to improve and enhance humankind, and to arrange individuals into a social pyramid built on the differences among individual qualities and humans' subsequent abilities to improve and enhance themselves. This way, society establishes the criteria upon which to decide who deserves to become an active member in it and who, in contrast, can form its passive substrate or has to be totally excluded.

Thanks to the secondary type of anthropotechnics, which nowadays corresponds to the available reproductive technologies - and their successive future development ${ }^{6}$, society validates Sloterdijk's political project of controlling and selecting humans through technology.

Sloterdijk draws inspiration for his ideas from Plato's Politikos, the dialogue where the Greek author discusses the best way to govern the polis and compares it to a zoological garden, a theme park. Here we can underline that the idea of a redesigned environment

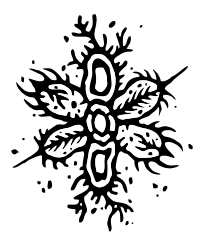
which determines the same human anthropology comes back repeatedly. Sloterdijk uses the Platonic zoo as a reference point for designing his society and showing how political concern is actually a reflection on the governance of the human zoo, precisely because the management of humans is a zoopolitical task. It is a type of political anthropotechnics which establishes the real political figure, i.e., someone whose power derives from "the royal knowledge of breeding" (Sloterdijk 2017b, 214).

Sloterdijk adapts the idea of the human zoo to his time - the technological era, reflecting on how to structure it in the best possible way:

It is the signature of the technological and anthropotechnological era that human beings become increasingly involved in the active or subjective side of selection, without having to be voluntarily thrust into the role of the selector. Additionally, one may observe that there is an unease in the power of choice; soon it will

6 The main possible development of the actual reproductive technologies is ectogenesis. This notion means the option to transfer partially and/or totally the generative process in an artificial womb: this would lead to control the foetus from the very moment of fecundation until birth, after having produced artificial embryos in laboratories. Nowadays ectogenesis is not a concrete possibility and it is theorized to save premature foetuses, but the first successful experiments have taken place. Doctor A. Flake and his team, at the Children's Hospital of Philadelphia, transferred some lamb foetuses in artificial bags which recreated the uterus conditions and they monitored them until the moment of birth. The limit for the transfer they pointed out is week 23 because the internal organs are not formed before then. Indeed, scientists do not yet know the formation process in details and the previous experiments with a goat's foetus failed. The experiment was published on Nature Communications and drew much attention in the scientific debate (Flake et al. 2017). 
become an instance of opting for innocence when human beings explicitly refuse to exercise the power of selection that they have in fact managed to achieve. But as soon as powers of knowledge are positively developed in a field, human beings cut a poor figure if they-as in earlier times of incapacity-wish to allow a higher force, whether it be God or chance or something else, to act in their stead (Sloterdijk 2017b, 211).

This is how Sloterdijk clarifies his intent to rebuild society based on this selfselective process: even though the selective mechanism is already present in it, if men discover a better way to implement it, they have a duty to use it in order to move to the active side of selection. This becomes the watershed according to which to exclude or include individuals in society: if, as Sloterdijk proposes, individuals have to deserve their place in society and have to position themselves on the social hierarchy, this becomes a way to create competition among them, to see who succeeds in becoming an active selector, avoiding 'any higher force to act in his stead'.

Thus, a clear distinction emerges between selectors - the ones who are saved and selected, and those ones who are excluded. Just as in the Ark metaphor, in the context of the transformation of the human environment into the form of the human park there is the same anti-egalitarian and anti-universalistic logic. And this represents the crucial and problematic outcome of Sloterdijk's entire redefinition of technology.

\section{The Imperative of Technology}

The need to transform both the human environment and the natural one through technology derives from the primacy of technology itself, i.e., the idea that technology is the only valuable criterion upon which to reconfigure society. Indeed, Sloterdijk seeks to turn the subject's ability to do something (I can, Ich kann in German) into a duty (I may, therefore I have to, Ich darf [I may] in German). In Sloterdijk's opinion, "the affective kernels of modern forward progress are the I-can [Ich-kann] and it's-a-go [Esgeht]" (Sloterdijk 2017c, 230). This implies that if something becomes possible, thanks to progress and technology, we must give it a chance, "give it a go", without considering beforehand whether it is right to do it or not. Furthermore, recalling the idea that the natural environment must change for it to be liveable for humans, every chance to transform it - including the modification of its inhabitants - is welcome and supported.

This way, since technology paves the way for new possibilities and, as outlined above, these possibilities therefore have to be realized, ethics becomes subordinated to technology just because of technological progress, which cannot be stopped in order for it to be evaluated.

Nevertheless, ethics cannot accept abdication in favour of a free and limitless technology: ethics remains the point of reference for making an evaluation, since ethical concerns comprehend every human action.

Notwithstanding, Sloterdijk does not take into consideration this implication 
and he does not question the idea of the park itself: his only concern is to find a code of anthropotechnics to manage the new power of self-breeding in a responsible way, thanks to the new anthropotechnical possibilities. Sloterdijk refers to a technical code, not an ethical one - as Tugendhat (1999, as cited in Musio 2005) highlights - because he considers the traditional ethical issues to be as dead as humanism. On the contrary, as the author of this paper has already shown, he tries to establish a new ethical system based on technologies, where ethics is subordinate to technology and where technological opportunities become the only way to concretize the pyramidal enhancement paradigm.

This pyramidal program elaborated on the concept of enhancement is based on an acritical imperative of efficiency: everyone has to be more efficient and there is no way of avoiding it. Indeed, as Giovanni Leghissa (2012) outlines, if an individual tries not to optimize himself, he is threatened with exclusion from the social dynamic, which has become a fight for the same subject's survival, based on the efficiency paradigm. Indeed, as outlined above, if technology becomes the only value to refer to, when there is the chance of enhancement there is a duty to achieve it, just because it is possible.

Nevertheless, Sloterdijk himself highlights how critical this paradigm is: human beings can reach their dignity and their value only if they prove to be successful in life. They must overcome their deficiencies in spite of any kind of original differences and conditions. This new form of perfection, based on performance, becomes the new ethical paradigm upon which human beings can be judged. As Sloterdijk observes, this ethicalanthropological 'in spite of' makes disability the baseline condition for every global consumer, who must be appraised on the preference market in spite of all his limitations. However, in his Il capitale in-umano, Alessio Musio (2016b) points out how Sloterdijk's considerations - and it is not clear whether Sloterdijk truly believes them or whether these are only musings - cannot be accepted, since they completely overturn the logic of human rights. Following this logic, people have value and dignity by virtue of being human beings, despite the possible differences amongst each other. In contrast, in Sloterdijk's considerations, this 'despite' becomes the starting point from which human beings can exceed their limitations and can acquire their dignity. Without this effort, they cannot survive under the imperative of efficiency. Indeed, this 'despite', which rereads the whole of human anthropology, constitutes the ethical duty humankind has in order to reshape the environment on a technological basis and, therefore, the polis as well.

However, as Musio (2016b, 312) underlines, if our value is based exclusively on the outcome of our efforts, the ethical-philosophical origin of human rights is lost. Sloterdijk says that ,it is no longer enough to be a human as one was supposedly spawned by nature; the dream of simple self-foundation via the origin is over" (Sloterdijk 2013, 328).

Therefore, with this refined move, Sloterdijk, again, makes a complete overhaul of the ethical paradigm, designating autonomy and self-selection as the highest values to reach, and anthropotechnics as the means to do so. Technology thus becomes a constitutive and definitive part of the human being, as well as of the environment, and 
this is why it becomes unfair and unjust to ignore it: concretely, this means that human beings have the duty to actualize their possibilities in order to be in charge of themselves. Therefore, if humans have the chance to select themselves also genetically, they must do so. As Sloterdijk famously says:

Whether long-term development will also lead to a genetic reform of attributes of the species-whether a future anthropotechnology will advance to an explicit planning of traits; whether humanity will be able to carry out, on the level of the species as a whole, a switch from the fatalism of births to optional birth and prenatal selection - these are questions with which the evolutionary horizon begins to clear before us, however indistinctly and frighteningly (Sloterdijk 2017b, 211).

Therefore, the last pieces of the broader picture that is Sloterdijk's project to establish a controlling society are manipulation and genetic planning. This way society becomes so powerful that it can reformulate even the notion of the human being, rebuilding it by basing it on the category of autonomy through the elimination of his natural contingency ${ }^{7}$. This is what Sloterdijk calls the fatalism of birth. Through technological support, society controls every step of human generation and decides who may or may not be born - this is what optional birth and prenatal selection really mean - not leaving to anybody else, 'whether it be God or chance or something else', the possibility to choose instead. Only Big $M o t h e r^{8}$ can have the power to shape its product - the human being.

Indeed, just as the environment no longer represents a mother-nature, but rather an evil stepmother, the act of human birth itself becomes a dangerous and uncontrollable

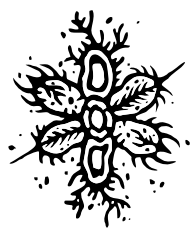
event in human life, which has to be monitored and dominated technologically.

However, Sloterdijk does not seem to realize the consequences of his theories, and he puts forward these futuristic possibilities without considering their most problematic aspects. In reality, he shies away from bringing his assumptions together in a concise theoretical overview because it would force him to realize that the house supporting his thought is made of cards, rather than solid foundations.

With all these technological revolutions - or involutions - Sloterdijk allows society to choose among individuals at a very early stage, and to decide how to domesticate and breed them. This controlling formula leads to the creation of automatons, raised by the rules of society. In order to create a hierarchy among people, not only on the basis of genetic manipulation, but rather during their entire life, Sloterdijk elaborates the theory of ascetism. Indeed, ascetism represents the last step of the anti-universalistic perspective of the philosopher, expressed by the idea of a repetition circuit from which it is very difficult to get free. Those who succeed in this process become the active and powerful

7 For an in-depth analysis of the topic, please refer to Musio (2012). The author faces the problematic significance of the elimination of this lemma, both for the definition of the human being and for its bioethical implications.

8 With 'Big Mother,' the author of this paper recalls Orwell's (1949) dystopic image of a totalitarian powerful society which controls every aspect of its citizens' lives. The reference highlights how Sloterdijk's idea of society can degenerate easily. 
members of technopolitics.

\section{Autonomy: The Dark Side of Asceticism}

Sloterdijk adds another element to his reconfiguration of the natural environment: he believes every human activity can be included in a repetition cycle that represents the way human beings learn how to produce themselves (Sloterdijk 2013). Indeed, the philosopher considers that human beings can only achieve their maximization through anthropotechnical repetition; this means that the individual is a subject who self-produces through the reiteration of a series of activities ${ }^{9}$. He includes in these activities all voluntary or involuntary disciplines with a technical substrate which define and determine human behaviours. Everything forms part of this repetition cycle, from religion to ethics to sport. Sloterdijk affirms that men produce men "through a life in form of practice” (Sloterdijk 2013 , 4). Once again, he severs every bond with the natural origin of humankind - i.e., the coming to the world - and its environment, therefore considering humankind as a technological self-production. Indeed, the only important thing is to distinguish between good and bad repetitions. Good repetitions are conscious practices that bring the individual to elevate himself in an attempt to constantly outdo himself. This leads the individual to improve his life condition until he manages to overcome the repetition circle and reach the ascetic form ${ }^{10}$, which coincides with his realization not as an automaton, but rather as a conscious subjectivity - indeed he calls this outcome de-automatization.

Although the idea to try to better oneself is good in itself, Sloterdijk uses it to classify and arrange human beings within his elitist project. In fact, individuals can affirm themselves only through their capacity to reiterate themselves, and not everyone has the same opportunities to do so. Furthermore, human beings can reach their subjectivity through a process that defines them - some of them ${ }^{11}$ - as the good products of repetition. Human beings are designed through the productive categories and are considered to be just like objects: they are completely controlled by the anthropotechnics that define them. In fact, even though there is a chance to abandon the repetition cycle, human beings improve themselves and form themselves within it; they are its product and not its master. After all, Sloterdijk designs the repetition cycle in a way that cannot be and must not be

9 As Graziella Berto $(2012,96)$ shows, what distinguishes Sloterdijk's idea of exercise from other types of practices is that there is a permanent condition of training, without a real conclusion. Individuals never acquire a stable form; it is always faltering, and it needs constant practice in order to be preserved. The danger of letting themselves be carried away by the flow is always present, therefore men must keep exercising.

10 Pier Aldo Rovatti $(2012,12)$ explains how having good discipline in continuing to exercise is not enough to reach the ascetic form, since repetition does not automatically contain the subjective disposition to improve oneself. Indeed, asceticism corresponds to a superior reality, to another life which is originally presented in anticipation to the individual and represents the final aim of the good practices.

11 It is not clear what happens to the ones who fail in the ascetic process: they stay in a fuzzy and intermediate dimension of indeterminacy. 
destroyed, as it represents the final outcome of his elitist technological revision of the environment.

Now, at first Sloterdijk's proposal may appear democratic, since he believes everyone starts from the same level. Humans are tempered by habits and customs, learnt through repetition, and they are not aware of this because they have grown accustomed to this cycle; then, some of them become conscious of this situation and release themselves through good practices, while others remain in their initial condition. At a second glance, however it becomes clear that this is a critical point, because it discriminates those who succeed from those who fail. In fact, this distinction leads inevitably to the idea that a part of the population cannot reach freedom from these conditionings and spend their entire lifetime in a state of no-subjectivity, i.e., in Sloterdijk's perspective, a permanent unconsciousness ${ }^{12}$.

The aim of the ascetic process should be to be free from any automatism and conditioning and to reach critical judgment through good repetitions. However, although the philosopher postulates ethical life as the achievement of de-automatization, he does not consider how he has already demolished any ethical content, levelling it just like every anthropotechnical practice ${ }^{13}$. He has not left any possibility to establish an ethical criterion, since ethics is subordinated to technology and it is not independent.

After all, the entire repetition system is based on the idea that men produce men through practice: if Sloterdijk provided a realistic solution to this vicious cycle, he would supply the key to deconstructing the new anthropotechnical environment he has

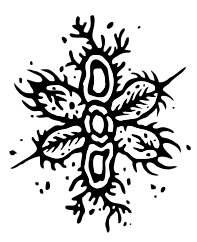
established.

This is yet another shift made by Sloterdijk without considering the consequences: it is a contradiction to place ethics at the end of the repetition cycle if it is impossible to define the specificity of ethics itself, and if ethics represents a practice within the cycle and not outside of it. It seems there is no way to leave the repetition circuit, because the ascetic process is unable to break its mechanism, since it is compromised from the beginning.

Furthermore, Sloterdijk definitively disempowers ethical content when he claims that the content of the practice is irrelevant, and that the only aspect to consider is the capacity to be active and to become increasingly autonomous. Indeed, as Alessio Musio

12 According to Sloterdijk's philosophical speculation, subjectivity coincides exclusively with consciousness. He rejects the idea of a constitutive subjectivity, excluding any form of ontological link. It becomes a quality someone can achieve - or not - through the ascetic process. Only if and once the subject concludes positively this process, can he recognize and define himself as conscious and ultimately autonomous.

13 Sloterdijk does not consider this point as relevant, wanting to avoid any link to God or metaphysics in order to establish the ethical content of life. Indeed, as Edoardo Greblo (2012, 108) outlines, ethics becomes a kind of intentional and wanted self-proxy, i.e., a dedication to a personal conversion to a better life. The single individual can decide, autonomously, what is good and what is bad, to evaluate his life as a success or a failure. However, this interpretation of ethics does not work even for Sloterdijk, since he theorizes a relevant difference between good and bad practices which is fundamental for reaching asceticism. Therefore, this is another critical point in his speculation, which remains open and unsolved. 
(2016a, 81) highlights, Sloterdijk argues that the way one can learn ethical content is the same way one can learn a language in Wittgenstein's theory. It is all about practice and repetition: without reflection.

However, life can be defined as a moral life when reflection, in the form of critical judgment, intervenes, deciding what, here and now, is objectively good to do (Musio 2016a, 82). Thus, habits and repetitions become virtues exclusively under these circumstances, i.e., when they are the result of a critical evaluation which has determined what deserves to be really exercised (because it is good) and what does not. Without this distinction between what is good and what is bad, there is no possibility to talk about ethics at all.

This is the crucial point in Sloterdijk's philosophical speculation, because he believes the only important thing is to achieve autonomy and the best way to become active and autonomous is 'to exercise the power of selection that they have in fact managed to achieve', i.e., to select and control human generation, eliminating the original passivity the fatalism of births ${ }^{14}$ - that characterizes human beings.

Sloterdijk's final aim is ultimately made explicit: the few who become subjects within society assume the power to control and select the others, since they have shown to be better than anyone else. Moreover, they have the duty to use their technologies to enhance society, and if this means to genetically control all the others, then they must do so. Asceticism becomes the selective criterion for inclusion and exclusion in the sphere of society, a discriminating way to arrange people into a hierarchy, on the basis of their capacity to escape the repetition cycle or not.

This is how Sloterdijk concludes his technopolitics project, by elaborating an artificial nature through which human beings can be controlled and selected. He has created a new technological environment in which his political goal - the antidemocratic society called technopolitics - finds its realization. Clearly, this is the culminating point of the excluding and discriminating project that is the human zoo.

However, Sloterdijk does not consider how powerful the natural environment is. He stretches it to the extreme consequences, trying to reshape it as if it were modelling clay at the disposal of humans; notwithstanding, the environment does not follow the anthropotechnical repetitions Sloterdijk elaborates for it. Nature itself works by its own repetitions, i.e., the succession of the seasons, the alternance between day and night, the tides, photosynthesis, and so on. These autonomous natural repetitions are so powerful

14 Sloterdijk plays with a specific definition of nature, intended as a chance that must be improved by technology in order to give it some rationality. As Sjoerd van Tuinen (2011) highlights, supporting Sloterdijk's perspective, there is a need for this intervention. "At work here is a technology mediated, intergenerational, or natal difference, which, by differentiating nature into a process with two sides - one of production, natura naturans, and one of its products, natura naturata - frees the creative force of life from its fixation on the side of the produced. Firstly, this difference forces us to understand technology as a production process in which there is no absolute difference between nature and 'human' technology. Secondly, it disallows us to reduce the essence of life to the prescriptive laws of what exists or to disconnect it from the laws of selftransgressing becoming. Thirdly, it makes us realise that life, no matter whether it is defined biologically, ecologically, or morally, cannot be restricted to the domain of an essentialistically defined humanity" (Tuinen 2011, 54). 
that not even a system like technopolitics is able to stop them. There is no way to redefine an environment which is already independent, and which forms the origin of humans: we can try to domesticate it and separate ourselves from it, but this attempt is doomed to failure; it is impossible to eradicate a thing's own nature.

\section{Conclusions}

Based on the considerations made thus far, it is now crucial to examine the conclusions Sloterdijk reached in order to evaluate the consistency of his theoretical proposal.

Sloterdijk's final aim was to establish a new social structure which is antidemocratic and elitist: technopolitics. This is the fundamental purpose which needs to be taken into consideration as the basis for every successive philosophical speculation and theory. However, this is an impossible purpose to realize, since Sloterdijk's speculation runs aground in its own short circuits. Indeed, as the present author has shown, Sloterdijk tries to completely redesign nature through technology, arguing for a separation between a human artificial environment, enclosed and safe, and an evil external nature.

Indeed, he relies on technology and its powers to defeat the natural course of life in order to design a new artificial nature, with all the implications this paradoxical concept presents within itself. However, this is just an attempt to modify in every possible way the same meaning of nature and of the subjects within it.

Thus, Sloterdijk builds his speculation on the notion of technology, considering it as the only reference value. Indeed, once Sloterdijk has made ethics collapse under technology, he can play this card every time he faces a contradiction, or he finds himself at a dead end. This way, he eliminates every obstacle to the establishment of this new technological environment.

Sloterdijk's thought is magmatic, a labyrinth in which it is easy to get lost. Nevertheless, if we analyse its premises, we can trace his line of thought back to its origins. His theories are based on three key concepts: the idea of an initial, dangerous natural environment we have to get rid of; the idea of humans as beings in progress; and the idea of technology as a solution to the previous issues.

Once these premises are put in place, Sloterdijk can reconfigure the original nature, the wet evil, into a redeeming technological product which makes it possible to live safely. This is the most crucial passage in the analysis presented in this paper: Sloterdijk's fundamental move consists in this redefinition of technology as the new creation of the environment and of humankind. Starting from this prerequisite, he then argues in favour of a reinterpretation of society, democracy and ethics through the forms of the human zoo, the 'despite' and the repetition cycle. In a word, technopolitics.

Now, a key issue tied up with Sloterdijk's philosophical speculation is his willingness to remain ambiguous. This leads him to simultaneously support overwhelmingly different 
positions which can easily become contradictions. As we have shown, technology represents the new artificial environment in which he founds his social project of the zoo. In order to establish this new system of controlling and selecting people hierarchically, Sloterdijk theorizes the fall of human rights logic and the impossible ascetic process. These are his instruments to keep his structure solid.

However, Sloterdijk's project is a failure because the basis on which he tries to build his zoo is not solid: there is no chance of a dominating and discriminating society without subjects. In fact, every society needs the possibility to establish human relationships, even powerful or controlling ones. Arguing against the formation of subjectivity, Sloterdijk prevents the constitution of the social pyramid: there cannot be societies amongst objects, as subjects are needed in order to establish any kind of human relationship. Who is going to govern the zoo if there are no real subjects at all?

Now, it is true that many different kinds of relationships ${ }^{15}$ can be established, and not only among people ${ }^{16}$. However, social and power relationships imply, at least at their origin, the presence of human beings. Therefore, referring to the project of Sloterdijk's human zoo, we can highlight a fundamental lack of this human element in the configuration of the social structure. This is a crucial point in the philosopher's theoretical itinerary, since it constitutes the lacking element that causes the collapse of the zoo. Indeed, on the one hand, if asceticism is a failure, nobody can reach the status of subjectivity and there is no opportunity to establish any human relationship at all. There is no power if there is nobody to impose power on - this seems to be the logical conclusion. On the other hand,

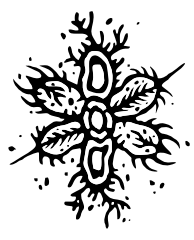
however, Sloterdijk clearly supports any intervention through genetic manipulation, which is hypothetically possible and increasingly concrete. In fact, there are some subjects who can be the object of a controlling power: children. They represent the object of selection, the ones who are manipulated. They are subjects in a passive sense, i.e., they are subjected to a power which dominates them.

Even though this second point is in evident contradiction with the first one, it is fundamental in order to explain Sloterdijk's final and real aim: to legitimate the actual and concrete possibilities of eugenics and their further developments.

However, this additional element represents another contradictory point in the philosopher's thought. Indeed, Sloterdijk tried to eliminate the biological aspect from mankind. With his overturn between nature and technology, he has postulated human beings as anthropotechnological products, with no bonds to their natural origin and

15 Indeed, according to Vanni Rovighi (1947), the relationship is not a being, a real entity, in itself: the subjects of the relationship exist truly, while the relationship in itself is just an ideal entity.

16 Relationships can be of any kind: as Nick Bostrom (2014) presents in his book, Superintelligence, nowadays we can think of relationships which do not need the human element. For example, social networks, like Facebook and Twitter, or financial trading are considered as juridical persons which establish relationships among themselves. Now, it is right to define them as juridical persons and to highlight how humans do not intervene in order to make them real. However, we do have to consider that an original human presence was necessary in order to create the social networks as well as the financial system or trade. Therefore, we can actually still argue in favor of the need of this initial human presence, at least when we refer to social dynamics as well as powerful ones. 
environment. However, once he argues in favour of genetic manipulation, he necessarily refers to the biological element of individuals: there is no possibility of selection if there is no biological matter to intervene upon. Therefore, his attempts to redesign and reconfigure the whole understanding of humans and their environment appear as a counter-productive move in his revolutionary plan. Indeed, in order to support this part of his elitist project, he should give back to nature its role as the humans' mother-nature, that mother who generates them as beings. With a body which can be modified and manipulated. However, this is an impossible step back that would damage the reconfiguration of the environment itself - which constitutes the foundation of the entire techno-polis.

Thus, the postulation of technology - as the key to re-reading the environment and ethics, and the resulting technological society redesigned on these bases, hierarchical and against human rights - becomes the reason for its own collapse. Technopolitics, initially theorized to validate the human zoo and to be its final outcome, turns into its own destruction.

A key contribution of the analysis made so far has been to highlight how a redefinition of the environment via technology becomes the powerful theoretical tool which entirely reconfigures Sloterdijk's philosophical itinerary. The problematic outcome of technopolitics shows the antidemocratic and elitist characteristics which derive from a redefinition of nature as a technological environment, which structures a polis based on a hierarchy among people. However, it is necessary to recognize the peculiarity of nature as an autonomous and independent environment which technology cannot control and destroy completely. Only in this way is it possible to give back to nature is crucial role, reconsidering technology as an artificial tool produced by humans and not their natural environment or their Ark to salvation.

Therefore, by reviewing Sloterdijk's philosophical speculation and evaluating his technological revolution, we can reassign to the environment its natural and original significance. Paradoxically, in order to re-establish ethics, democracy and human rights, Sloterdijk's reflections are crucial. Indeed, Sloterdijk's upside down turns can be interpreted as a proof of the crucial significance of these concepts.

\section{References}

Berto G. 2012. "Perdere la testa. Ginnastica e filosofia," Aut Aut 355:95-105.

Bostrom N. 2014. Superintelligence. Paths, Dangers, Strategies. Oxford: Oxford University Press.

Calligaris A. 2001. "Il dibattito che non c'è stato," Aut Aut 301-302:111-119.

Couture J. P. 2016. Sloterdijk. Cambridge: Polity Press. 
Flake A., Davey M., Hornick M., McGovern P., Mejaddam A., \& Vrecenak J. et al. 2017. "An Extra-uterine System to Physiologically Support the Extreme Premature Lamb," Nature Communications 8(1). DOI: 10.1038/ncomms15112.

Greblo E. 2012. "Mi esercito, dunque sono," Aut Aut 35:106-116.

Leghissa G. 2012. "L'esercizio come condizione di possibilità del soggetto (e della sua sparizione)," Aut Aut 355:19-36.

Lucci A. 2011. Il limite delle sfere. Saggio su Peter Sloterdijk. Roma: Bulzoni.

Mendieta E. 2012. "A Letter on Überhumanismus: Beyond Posthumanism and Transhumanism," in S. Elden (Ed.), Sloterdijk Now (pp. 58-76). Polity Press.

Musio A. 2005. "La casualità dell'uomo e la rinascita del pensiero in margine ad alcune voci della filosofia pratica tedesca," Rivista di Filosofia Neo-Scolastica 97(1):105130. Retrieved from http://www.jstor.org/stable/43063613.

Musio A. 2012. "Il 'pathos' della decisione: una lettura filosofica attraverso la generazione," Medicina e Morale 15:713-731.

Musio A. 2016a. Chiaroscuri. Figure dell'ethos. Milano: Vita e Pensiero.

Musio A. 2016b. "Il capitale in-umano. La bioetica di fronte al 'lavoro clinico'," Medicina e Morale 3:293-314.

Orwell G. 1949. Nineteen Eighty-Four. London: Secker \& Warburg.

Rovatti P. A. 2012. "Esercizi ma senza ascesi," Aut Aut 355:7-18.

Sloterdijk P. 2011. Bubbles. Sphere Volume I: Microspherology. Los Angeles: Semiotext(e). Sloterdijk P. 2013. You Must Change Your Life. On Anthropotechnics. Cambridge: Polity Press.

Sloterdijk P. 2014. Globes. Spheres Volume II: Macrospherology. Los Angeles: Semiotext(e).

Sloterdijk P. 2016. Foams. Spheres Volume III: Plural Spherology. Los Angeles: Semiotext(e).

Sloterdijk P. 2017a. "The Domestication of Being. The Clarification of the Clearing," in idem, Not Saved. Essays after Heidegger. Cambridge: Polity Press.

Sloterdijk P. 2017b. "Rules for the Human Park," in idem, Not Saved. Essays after Heidegger. Cambridge: Polity Press.

Sloterdijk P. 2017c. "Wounded by Machines. Toward the Epochal Significance of the Most Recent Medical Technology," in idem, Not Saved. Essays after Heidegger. Cambridge: Polity Press.

Tillería Aqueveque L. E. 2020. "Homo Sloterdijk: filosofía de la tecnología en la Posmodernidad," Sophia 28:67-90. DOI: 10.17163/soph.n28.2020.02.

Tuinen S. 2011. “Transgeneous Philosophy': Posthumanism, Anthropotechnics and the Poetics of Natal Difference," in W. Schinkel \& L. Noordegraaf-Eelens (Eds.), in Medias Res. Peter Sloterdijk's Spherological Poetics of Being (pp. 43-66).

Amsterdam: Amsterdam University Press.

Vanni Rovighi S. 1947. Elementi di filosofia. Brescia: La Scuola. 